\title{
Isolation and characterization of Mycobacterium avium subspecies paratuberculosis in Korean black goat (Capra hircus aegagrus)
}

\author{
Aislamiento y caracterización de Mycobacterium avium subespecie paratuberculosis \\ en cabras negras coreanas (Capra hircus aegagrus)

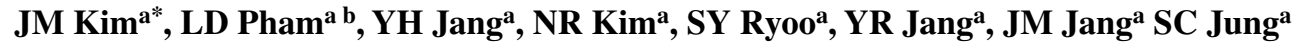 \\ ${ }^{a}$ Animal and Plant Quarantine Agency, Anyang, Gyeonggi-do, Korea. \\ bNational Institute of Animal Sciences, Tuliem, Hanoi, Vietnam.
}

\begin{abstract}
RESUMEN
La paratuberculosis, causada por Mycobacterium avium subsp. paratuberculosis (MAP), es una infección crónica e incurable del tracto intestinal de los animales. El estudio se realizó en 2012, usando muestras procedentes de 491 cabras negras coreanas, menores de 2 años, procedentes de un rebaño caprino de la región Sur de Corea. Los animales se evaluaron para detectar presencia de paratuberculosis. Los métodos utilizados para investigar las infecciones por MAP fueron ensayo por inmunoabsorción ligado a enzimas y cultivos microbiológicos. De las 491 cabras de 100 rebaños seleccionados, $4(0,8 \%)$ y $3(0,6 \%)$ dieron resultados positivos para MAP en la prueba de ELISA y el estudio microbiológico de coprocultivo, respectivamente. Las colonias aisladas fueron confirmadas como MAP por IS900-PCR y su tipificación se realizó por medio del ensayo de IS1311 PCR-REA. Los resultados revelaron una baja tasa de prevalencia de infecciones por MAP de cepas de "tipo bovino" y "tipo bisonte".
\end{abstract}

Palabras claves: cabra, Mycobacterium avium subsp. paratuberculosis, cultivo.

\section{SUMMARY}

Paratuberculosis, caused by Mycobacterium avium subsp. paratuberculosis (MAP), is a chronic incurable infection of intestinal tract of animals. The study took place in 2012, on 491 Korean black goats, older than 2 years, from goat herds located in Southern region, Korea. The animals were sampled and tested for paratuberculosis. Enzyme-linked immunosorbent assay and microbiological culture were used to investigate MAP infection. Among the 491 goats from 100 herds screened, $4(0.8 \%)$ and $3(0.6 \%)$ goats were defined positive for MAP by ELISA and faecal culture, respectively. Isolated colonies were confirmed as MAP by IS900-PCR, and genotyped by IS1311 PCR-REA assays. The results revealed MAP infection at a low prevalence rate with "cattle type" and "bison type" genotypes.

Key words: goat, Mycobacterium avium subsp. paratuberculosis, culture.

\section{INTRODUCTION}

Mycobacterium avium subspecies paratuberculosis (MAP) is the causative agent of paratubercuolosis or Johne's disease, chronic intractable enteritis that affects many domestic and wildlife animals. It may also be the causative agent of Crohn's disease in human (Quirke 2001) although the zoonotic potential of MAP is a controversial issue. MAP infection occurs worldwide and has a significant impact on economic losses in ruminants (Ott et al 1999). The control and eradication of this disease is difficult partly due to the lack of a reliable, sensitive, and specific diagnosis test. Paratuberculosis in small ruminants is widely distributed in several European countries, such as France (Mercier et al 2010), Greece (Dimareli-Malli et al 2013) as well as in many Asian

Accepted: 02.01.2015.

* kimjm88@korea.kr countries (Kumthekar et al 2013, Lee et al 2006). On the American continent caprine paratuberculois has been reported in USA (Pithua and Kollias 2012), Canada (Debien et al 2013) and Chile (Kruze et al 2006). Black goat is a type of indigenous breed of Korea, and its population is estimated at 266,000 animals in about 21,000 herds; it comprises the majority of small ruminant herds in the country ${ }^{1}$. Korean black goats are mainly raised for meat and healthy food supplement. Currently, although caprine paratuberculosis is known to be present in Korea, very little information of MAP infection in Korean black goat is available (Lee et al 2006). Moreover, no study was conducted to identify animals that were either negative or positive by faecal culture. This study reports the results of an investigation on MAP infection in Korean black goat by using ELISA, faecal culture and molecular assays.

KOSIS, Korean Statistical Information System. 2012. Daejeon, Republic of Korea. http://kosis.kr/eng/ 


\section{MATERIAL AND METHODS}

ANIMAL SAMPLING

The serum and faecal samples of each 491 Korean back goats ( $\geq 1$ year of age) from 100 goat herds in 6 provinces of Korea: Chungbuk, Chungnam, Gyeongnam, Gyeongbuk, Jeonbuk, and Jeonnam were randomly collected from March to November 2012.

ELISA

A commercially available ELISA kit (Institute Pourquier, Montpelier, France, ELISA paratuberculosis antibody screening) was used to detect MAP antibodies in the serum. The positives were defined as the sample-to-positive ratio greater than or equal to 0.55 as suggested by the manufacturer.

\section{BACTERIOLOGY}

Faecal samples were cultured on Herrold's Egg-Yolk medium (HEYM) as described by Whipple et al (1991). Two grams of each sample were homogenized and decontaminated with hexadecylpyridinium (HPC) $0.9 \%$ overnight, and were centrifuged at $3500 \mathrm{x} g$ for $20 \mathrm{~min}$. Pellets suspended in $1 \mathrm{~mL}$ of antibiotic solution (vancomycin $100 \mathrm{mg} / \mathrm{ml}$, nalidixic acid and amphotericin B $50 \mathrm{mg} / \mathrm{ml}$ ) overnight and an aliquot of $150 \mathrm{ul}$ was inoculated onto four slants of Herrold's medium (HEYM) with mycobactin J. Cultures were incubated at $37 \otimes$ for up to 5 months.

\section{MOLECULAR CONFIRMATION}

DNA extraction from colonies was performed using DNeasy Blood \& Tissue Kit (Qiagen, USA) according to the manufacturer's instruction. MAP confirmation was performed as previously described (Moss et al 1992), with some modifications. The primers P90 (5'-GTT CGG GGC CGT CGT TTA GG-3') and P91 (5'-GAG GTC GAT CGC CCA CGT GA-3') were used for the amplification of a 400-bp fragment. PCR was performed in the PCR premix (AccuPowerTM PCR HotStart PreMix kit, Bioneer, Korea) by adding $10 \mathrm{pmol}$ of each primer and $2 \mu \mathrm{L}$ of DNA template. Amplification was carried out using a Biometra T3000-Thermoblock (Germany), with a denaturation step at $94{ }^{\circ} \mathrm{C}$ for $5 \mathrm{~min}$, followed by 35 cycles of $94{ }^{\circ} \mathrm{C}$, $1 \mathrm{~min} ; 58^{\circ} \mathrm{C}, 1 \mathrm{~min} ; 72^{\circ} \mathrm{C}, 1 \mathrm{~min}$, and a final extension at $72{ }^{\circ} \mathrm{C}$ for $10 \mathrm{~min}$. The PCR products were separated by electrophoresis on a $1.5 \%$ agarose gel, stained using RedSafe $^{\mathrm{TM}}$, and visualised under ultraviolet light. Negative and positive MAP controls were included.

TYPING

Strain typing of MAP isolates was done as previously described (Marsh et al 1999, Whittington et al 2001). The PCR amplification of IS1311 sequence was performed by using primers M56 (5'-GCG TGA GGC TCT GTG GTG AA-3') and M119 (5'- ATG ACG ACC GCT TGG GAG AC-3'). The PCR conditions were a denaturation step at $94{ }^{\circ} \mathrm{C}$ for $5 \mathrm{~min}$, followed by $35^{1}$ cycles of $94{ }^{\circ} \mathrm{C}, 30 \mathrm{~s}$; $62{ }^{\circ} \mathrm{C}, 15 \mathrm{~s} ; 72{ }^{\circ} \mathrm{C}, 1 \mathrm{~min}$, and a final extension at $72{ }^{\circ} \mathrm{C}$ for $10 \mathrm{~min}$. The 608-bp PCR product was digested using HinfI enzyme (Enzynomics ${ }^{\mathrm{TM}}$, Korea). The restriction products were separated by electrophoresis on a $2 \%$ agarose gel, stained using RedSafe ${ }^{\mathrm{TM}}$, and visualised under ultraviolet light. The cattle, sheep, and bison types were defined according to HinfI enzyme digestion patterns.

\section{RESULTS AND DISCUSSION}

Among the 491 goats from 100 herds screened, 4 $(0.8 \%)$ and $3(0.6 \%)$ goats were defined positive for MAP by ELISA and faecal culture, respectively. Only 1 goat $(0.2 \%)$ was positive for MAP in both ELISA and faecal culture tests. The discrepancies were observed in 5 goats, in which 3 goats were positive for MAP by ELISA but showed negative results by faecal culture test and 2 goats were negative for MAP by ELISA but were detected positive by culture test (table 1). Both ELISA and faecal culture tests revealed that 6 goats $(1.2 \%)$ in 6

Table 1. ELISA and faecal culture test results for Mycobacterium avium subsp. paratuberculosis in 491 Korean black goats. Resultados ELISA y coprocultivo para Mycobacterium avium subsp. paratuberculosis en 491 cabras negras coreanas.

\begin{tabular}{|c|c|c|c|c|}
\hline Geographical areas & Number of animals & Number of herds & $\begin{array}{l}\text { ELISA-positive } \\
(\text { animals/(\%) })\end{array}$ & $\begin{array}{l}\text { Faecal culture-positive } \\
\quad(\text { animals } /(\%))\end{array}$ \\
\hline Chungbuk & 81 & 20 & $1(1.2)$ & 0 \\
\hline Chungnam & 33 & 9 & $1(3.0)$ & $1(3.0)$ \\
\hline Gyongnam & 150 & 34 & $2(1.3)$ & 0 \\
\hline Gyongbuk & 81 & 22 & 0 & 0 \\
\hline Jeonbuk & 51 & 5 & 0 & 0 \\
\hline Jeonnam & 95 & 10 & 0 & $2(2.1)$ \\
\hline Total & 491 & 100 & $4(0.8)$ & $3(0.6)$ \\
\hline
\end{tabular}


different herds (6\%) were positive for MAP. The MAP infection was detected in four (Chungbuk, Chungnam, Gyongnam and Jeonnam) of six provinces investigated. All the 3 isolates were positive for IS900 PCR that confirmed as MAP. In Korea, the first identification of MAP pathogen from bovine was reported in 1984. Since then, several studies have conducted serological test for MAP infection in domestic livestock. According to previous studies, the seroprevalence has been reported to be $0.7 \%$ and $5.8 \%$ for beef and dairy cattle, respectively, at the nation-wide level (Park et al 2006). The seroprevalence of $1.2 \%$ and $6.1 \%$ was found for beef cattle and dairy cattle, respectively, in Gyeongnam provine (Lee and Jung 2009). In elk, the seroprevalence at animal level was estimated to be $8.2 \%$ (Kim et al 2012). The apparent prevalence found in this study is consistent with previously reported seroprevalence for beef cattle and lower than in dairy cattle and elk in Korea. Compared with many European countries (Nielsen and Toft 2009), which the prevalence of MAP was found to be more than 50\% at herd level, the prevalence of MAP in Korean black goat are fairly low. A previous study estimated the seroprevalence of MAP in Korean black goat at the time in period 2005-2006 and showed it to be $8.2 \%$ at the animal level and 25\% at the herd level (Lee et al 2006). It was considerably higher than that of the present study. In this regard, the difference in diagnosis test used, time point analysed, sampling designs and target populations were the possible reasons for the differences in prevalence results. On the other hand, the decrease of MAP infection in Korean black goat may also be explained by the recent improvement of breeding system and sanitary practices at goat farms, although no national control program has been implemented at the farm level in Korea. ELISA is the most commonly used diagnostic test for MAP because it is simple, fast, and cost-effective, while microbiological culture is considered the "gold standard" and definitive method to diagnose Johne's disease. In this study, the combination test showed a higher positive detection rate of goats for MAP (6 goats) compared to ELISA (4 goats) and faecal culture (3 goats) alone. This discrepancy between ELISA and culture results may arise from low quantities and irregular shedding of MAP in goat faeces detected by culture (Kralik et al 2011). And also the different results between ELISA and faecal culture tests in 5 goats reflected the deference in sensitivity. This suggests that multiple tests are necessary for the accurate diagnosis of MAP infection.

Genotyping of MAP isolates by IS1311 PCR-REA revealed that two isolates were "cattle type" which resulted in fragments of 323,285,218, and $67 \mathrm{bp}$ and one isolate was "bison type" which resulted in fragments of 323 and 218 and $67 \mathrm{bp}$ (figure 1). Knowledge about the status and genotype of MAP is needed to develop diagnostic methods and design a disease control program. The "cattle type" was commonly detected in wide host range of animals in

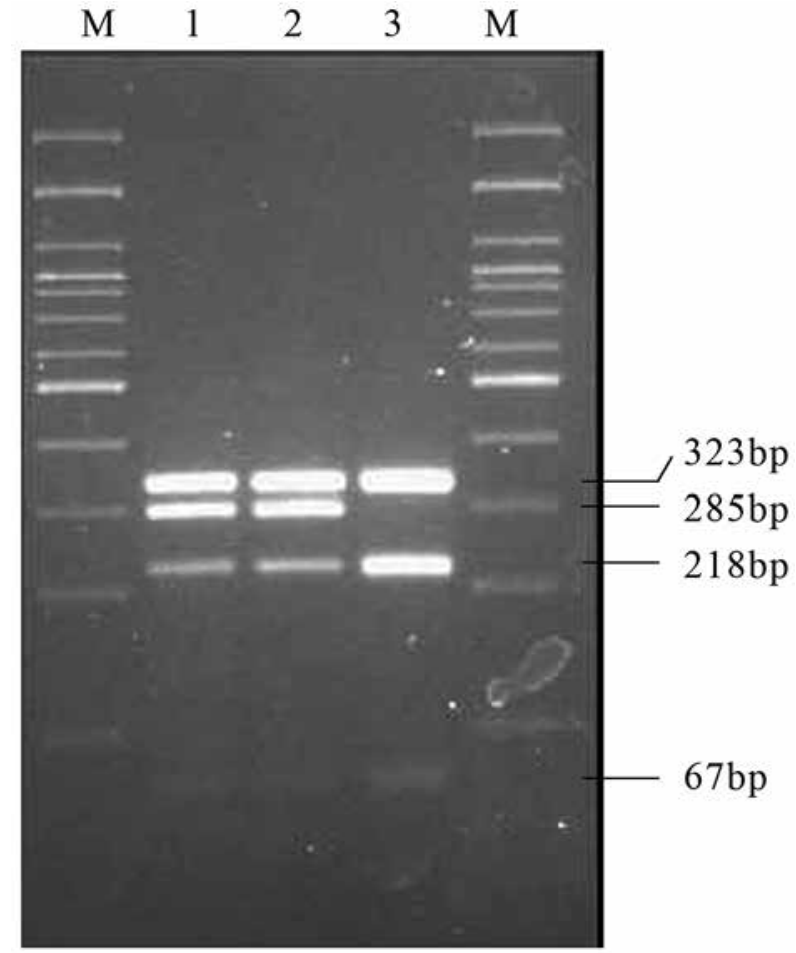

Figure 1. Agarose gel electrophoresis of IS1311 PCR products digested with HinfI. Lanes 1, 2: "cattle type"; lane 3: "bison type"; M: molecular marker (100 bp; Bioneer).

Electroforesis de los productos de PCR IS1311 digerido con HinfI gel de agarosa. Rutas 1, 2: "ganado tipo"; carril 3: "el tipo del bisonte"; M: marcador molecular (100 bp; Bioneer).

different parts of the world (Sevilla et al 2005). Moreover, most reports refer that goats are more ofteninfected with "cattle type" (Collins et al 1990, Whittington et al 1998). The "bison type" was found to be predominant genotype infecting domestic and wild ruminants in India (Singh et al 2010). Recently, however, limited data of MAP genotype from different goat populations worldwide is available. To our knowledge, this is the first study to report isolation and molecular genotyping of MAP in Korean black goat. Further, to the best of our knowledge, except for a study (Okuni et al 2012), in which the "bison type" was observed in Ugandan cattle, no other observation of the "bison type" genotypes are not commonly reported outside India or the USA. Furthermore, we also identified "cattle type" and "bison type" genotypes of MAP infected wild boar in Korea (Kim et al 2013). These results indicate that these two genotypes are a major cause of infection in domestic and wild animals in Korea.

In conclusion, the results obtained in this study showed serological, microbiological, and molecular evidence of MAP infection in Korean black goat with both "cattle type" and "bison type" genotypes. Therefore, there is a need to implement a national MAP control program in order to reduce the incidence and limit transmission among animal species. 


\section{ACKNOWLEDGEMENT}

This study was financially supported by Animal and Plant Quarantine Agency, Ministry of Agriculture, Food and Rural Affairs, Republic of Korea (Project No. B-1541778-2012-12-01).

\section{REFERENCES}

Collins DM, DM Gabric, GW de Lisle. 1990. Identification of two groups of Mycobacterium paratuberculosis strains by restriction endonuclease analysis and DNA hybridization. J Clin Micro 28, 1591-1596.

Debien E, P Helie, S Buczinski, A Leboeuf, D Belanger, R Drolet. 2013. Proportional mortality: A study of 152 goats submitted for necropsy from 13 goat herds in Quebec, with a special focus on caseous lymphadenitis. Can Vet J 54, 581-587.

Dimareli-Malli Z, K Mazaraki, K Stevenson, P Tsakos, A Zdragas,V Giantzi, E Petridou, I Heron, G Vafeas. 2013. Culture phenotypes and molecular characterization of Mycobacterium avium subsp. paratuberculosis isolates from small ruminants. Res Vet Sci 95, 49-53.

Kim JM, BK Ku, HN Lee, IY Hwang, YB Jang, JH Kook, SC Jung. 2012. Seroprevalence of Mycobacterium avium subspecies paratuberculosis in elks in Korea. Vet Rec 170, 102

Kim JM, BK Ku, HN Lee, IY Hwang, YB Jang, J Kim, BH Hyun, SC Jung. 2013. Mycobacterium avium subspecies paratuberculosis in wild boars in Korea. $J$ Wildl Dis 49, 413-417.

Kralik P, I Slana, A Kralova, V Babak, RH Whitlock, I Pavlik. 2011. Development of a predictive model for detection of Mycobacterium avium subsp. paratuberculosis in faeces by quantitative real time PCR. Vet Microbiol 149, 133-138.

Kruze J, M Salgado, E Paredes, A Mella, MT Collins. 2006. Goat paratuberculosis in Chile: first isolation and confirmation of Mycobacterium avium subspecies paratuberculosis infection in a dairy goat. J Vet Diagn Invest 18, 476-479.

Kumthekar S, EJ Manning, P Ghosh, K Tiwari, RN Sharma, H Hariharan. 2013. Mycobacterium avium subspecies paratuberculosis confirmed following serological surveillance of small ruminants in Grenada, West Indies. $J$ Vet Diagn Invest 25, 527-530.

Lee KW, BY Jung, OK Moon, DK Yang, SH Lee, JY Kim, CH Kweon. 2006. Seroprevalence of Mycobacterium avium subspecies paratuberculosis in Korean black goats (Capra hircus aegagrus). $J$ Vet Med Sci 68, 1379-1381.

Lee KW, BY Jung. 2009. Seroprevalence of Mycobacterium avium subspecies paratuberculosis in cattle in Korea. Vet Rec 165, 661-662.

Marsh I, R Whittington, D Cousins. 1999. PCR-restriction endonuclease analysis for identification and strain typing of Mycobacterium avium subsp. paratuberculosis and Mycobacterium avium subsp. avium based on polymorphisms in IS1311. Mol Cell Prob 13, 115-126.

Mercier P, C Baudry, F Beaudeau, H Seegers, X Malher. 2010. Estimated prevalence of Mycobacterium avium subspecies paratuberculosis infection in herds of dairy goats in France. Vet Rec 167, 412-415.

Moss MT, JD Sanderson, ML Tizard, J Hermon-Taylor, FA el-Zaatari, DC Markesich, DY Graham. 1992. Polymerase chain reaction detection of Mycobacterium paratuberculosis and Mycobacterium avium subsp silvaticum in long term cultures from Crohn's disease and control tissues. Gut 33, 1209-1213.

Nielsen SS, N Toft. 2009. A review of prevalences of paratuberculosis in farmed animals in Europe. Pre Vet Med 88, 1-14.

Okuni JB, CI Dovas, P Loukopoulos, IG Bouzalas, DP Kateete, ML Joloba, L Ojok. 2012. Isolation of Mycobacterium avium subspecies paratuberculosis from Ugandan cattle and strain differentiation using optimised DNA typing techniques. BMC Veterinary Research 8, 99.

Ott SL, SJ Wells, BA Wagner. 1999. Herd-level economic losses associated with Johne's disease on US dairy operations. Prev Vet Med 40, 179-192.

Park KT, J Ahn, WC Davis, HC Koo, NH Kwon, WK Jung, JM Kim, SK Hong, YH Park. 2006. Analysis of the seroprevalence of bovine paratuberculosis and the application of modified absorbed ELISA to field sample testing in Korea. J Vet Sci 7, 349-354.

Pithua P, NS Kollias. 2012. Estimated prevalence of caprine paratuberculosis in boer goat herds in missouri, USA. Vet Med Int 2012, 674085.

Quirke P. 2001. Antagonist. Mycobacterium avium subspecies paratuberculosis is a cause of Crohn's disease. Gut 49, 757-760.

Sevilla I, SV Singh, JM Garrido, G Aduriz, S Rodriguez MV Geijo, RJ Whittington, V Saunders, RH Whitlock, RA Juste. 2005. Molecular typing of Mycobacterium avium subspecies paratuberculosis strains from different hosts and regions. Rev Sci Tech 24, 1061-1066.

Singh AV, SV Singh, PK Singh, JS Sohal. 2010. Genotype diversity in Indian isolates of Mycobacterium avium subspecies paratuberculosis recovered from domestic and wild ruminants from different agroclimatic regions. Comp Immuno Microbiol Infect Dis 33, e127-131.

Whipple DL, DR Callihan, JL Jarnagin. 1991. Cultivation of Mycobacterium paratuberculosis from bovine fecal specimens and a suggested standardized procedure. J Vet Diagn Invest 3, 368-373.

Whittington RJ, IB Marsh, E Choy, DE Cousins. 1998. Polymorphisms in IS1311, an insertion sequence common to Mycobacterium avium and M. avium subsp. paratuberculosis, can be used to distinguish between and within these species. Mol Cell Prob 12, 349-358.

Whittington RJ, IB Marsh, RH Whitlock. 2001. Typing of IS 1311 polymorphisms confirms that bison (Bison bison) with paratuberculosis in Montana are infected with a strain of Mycobacterium avium subsp. paratuberculosis distinct from that occurring in cattle and other domesticated livestock. Mol Cell Prob 15, 139-145. 